Arab Univ. J. Agric. Sci., Ain Shams Univ., Cairo, 13(2), 513-519, 2005

\title{
OCCURANCE OF LAYING WORKERS AT DIFFERENT HONEY BEE COLONIES STATUS
}

[33]

\author{
Elbassiouny ${ }^{1}$, A.M.
}

\begin{abstract}
Laying workers expressed as Workers with Activate Ovaries (WAO) having mature oocytes had been studied in colonies headed with natural mated carnica queens. The results showed that the WAO were affected by the age of the queen, where it reached $0.8,1.3$ and $2.2 \%$ for colonies headed with queens 10, 20 and 30 month old, respectively. The worker ovaries started to activate when the reached 22.18 and 12 days from emergence for colonies headed with caged mated queens, caged virgin queens and queenless colonies, respectively. Also, when the worker's age reached 30 days, the percentages of WAO occurrence reached 3.3, 7.3 and $14.7 \%$ for the corresponding colonies status, respectively. In preparing swarm boxes, when the beekeepers failed to introduce the queens into the nuclei until two days, one week and two weeks, the WAO recorded 1.4, 4.8 and $9.2 \%$, respectively. In case of queen rearing, the presence of WAO was not significant until the fifth day, and then increased gradually to reach an average of $4.6 \%$ in the tenth day.
\end{abstract}

Key words: Honey bee, Apis mellifera, Laying workers, Oocytes, Ovarioles.

\section{INTRODUCTION}

Laying workers are usually the result of neglect or poor beekeeping. In spite of the presence of female reproductive system in worker bees which produces viable eggs, the activation of this system occurs when the colony becomes hopelessly either queenless (Jay, 1970) or broodless (especially open brood). Worker's brood keeps the worker's ovaries inactive until the new queen emerges to head the colony (Seeley, 1985).

In normal colonies, when a queen or it's worker larvae is present, workers ceased from laying eggs by mutual policing behaviour in which any rare workerlaid eggs are rapidly removed or destroyed by other workers (Visscher, 1996 and Katzav et al 2003).

Nurse bees offered food to the laying workers via trophallactic exchange (trophallactic behaviour) of royal jelly (Hogendoorn \& Velthuis 1988 and Hilleshein et al 1989), where it has a higher nutritive value for worker's ovary of either size (Blom \& Verkade, 1991) or development (Lin \& Winston, 1998). Thereby, these laying workers attained the status of a false queen and were con-

1- Plant Protection Department, Faculty of Agriculture, Ain Shams University, Shoubra El-Kheima, Cairo, Egypt

(Received January 2, 2005)

(Accepted January 9, 2005) 
stantly attended by nurse workers. Moreover it appeared to behave in all ways like a true queen (Seeley, 1985) but less aggressive as compared with those with undeveloped ovaries (Blom, 1993).

Laying workers are arrhenotoky except Apis mellifera capensis which are occasionally parthenogenetically thelytoky (Moritz et al 1998). The interval between dequeening and the beginning of egg laying by worker bees (latency period) shows significant variation depending on genetic diversity either between races (Woyke, 1993) or within race (Evers and Seeley, 1986). .Also colony status plays an important role for starting egg laying by workers (Hoover et al 2003), as Harris and Harbo (1989) stated that workers started to lay eggs after an average of 8.25 days from dequeening. The presence of laying workers decreased significantly the number of either accepted new queens introduced into queenless colonies (DeGrandi \& Martin 1993) or queen larvae (queen cells) in queen rearing colonies (Woyciechowski \& Radwan, 1988).

The aim of the present work is to investigate the occurrence of laying workers expressed by Workers with Activate Ovaries (WAO) as affected by colonies status under Egyptian beekeeping conditions.

\section{MATERIAL AND METHODS}

Laying workers indicated by mature oocytes were studied in colonies headed with natural mated local Carnica queens (Apis mellifera carnica) at the apiary of the Faculty of Agriculture, Ain Shams University during spring and autumn seasons, 2004. 100 individuals of adult workers from each replicate of the fol- lowing experiments were randomly collected, preserved in alcoholic Bouin's solution to permit the separation of ovarioles without tearing or breaking them when examined under a dissecting microscope. Each worker was dissected by cutting the abdominal tergum along the middorsal line and fixed in a Petri dish containing wax by means of minute nadlen pins.

The following experiments were carried out to indicate WAO by presence of mature oocytes in its ovarioles:

\section{Age of queens in queen right colonies}

Thirty queen right colonies were divided into three groups according to the queen's working ages inside the hive, ten colonies (replicates) each as follows: $1^{\text {st }}$ group composed of queens 10 month old; $2^{\text {nd }}$ group included queens aged 20 months and the $3^{\text {rd }}$ group contained queens 30 month old

\section{Age of workers}

Sealed worker brood combs were collected from different colonies and kept as a second hive body (second store) above the screen excluder with 8 mesh holes over a strong colonies. Soon after emergence, the newly emerged workers were introduced into the swarm boxes; each contained two combs full of honey and pollen. The swarm boxes were divided into 3 groups (3 colonies (replicates) each), where the first group headed with caged mated queens, the second headed with caged virgin queens and the third one was queenless. After ten days, dissecting workers from each tested swarm box were started and continued with interval of two days until the worker's age 
reached thirty days. Also, the number of ovarioles in each ovary was counted using thirty adult workers randomly collected and prepared as previously mentioned for dissection.

\section{Swarm production}

The beekeepers tend to increase their colonies either in the spring or in the autumn by division the colony; they do this process early before introducing the virgin queen into the new division with a period of a time lasted occasionally two days or more. Moreover, sometimes they were failed to find the new queens in suitable time. This experiment was conducted using five swarm boxes (replicates) to examine the occurrence of WAO after two days, one week and two weeks before introducing the virgin queens into the producing swarms.

\section{Queen rearing}

In the queen rearing processes for commercial purposes, the colonies in the present beekeeping conditions used as a starter and finisher (double purposes) for queen cells. So, the colonies were occupied for about ten days.

Queen rearing using grafting method was carried out in five colonies (replicates), each was prepared as follow: Queen with brood combs covered with bees was transferred into swarm box which move to new place in the apiary. The original colony with the remaining bees was prepared as a starter colony with two well filled combs of honey and pollen, a space was left between them for the grafting queen cells frame. The colony was also supplied with feeder placed next to the outer side of honey comb. Workers were collected daily for dissection, starting from rearing day until the tenth day from grafting.

\section{RESULTS AND DISCUSSION}

Laying workers can not be discriminate phenotypically (morphologically) from the normal workers. In the normal colony it was expressed by the presence of workers having mature oocytes which were found in many cases pursuant to the colony status.

\section{Age of queens in queen right colonies}

The queen's age plays an important role for the tendency of the worker's ovaries to develop, where the oogonia transformation into oocytes, but with different degrees according to the queen's age, where $0.8,1.3$ and $2.2 \%$ of WAO were found for colonies headed with queens 10, 20 and 30 month old, respectively, Table (1). The analysis of variance showed significant differences between WAO in colonies headed with 30 month old queens (more than two years) and colonies headed with either 10 or 20 months old queens (less than two years). This caused by an obvious decrease in vitality and the viability of the queen. This may be due to the weakness of pheromone released by queens which inhibits the ovarian development (Jay, 1970).

\section{Age of workers}

The worker's age is considered as one of the most important parameters for the tendency of worker's ovary to activate according to the colony status. 
Table 1. Percentages of Workers with Activate Ovaries (WAO)as expressed by presence of mature oocytes in normal colonies headed with different queen's ages

\begin{tabular}{|cccc|}
\hline \multirow{2}{*}{ Rep. } & \multicolumn{3}{c|}{$\begin{array}{c}\text { \% of WAO in colonies with } \\
\text { queen's ages (months) }\end{array}$} \\
\cline { 2 - 4 } & 10 & 20 & 30 \\
\hline 1 & 0 & 2 & 1 \\
2 & 1 & 3 & 3 \\
3 & 2 & 0 & 2 \\
4 & 0 & 1 & 0 \\
5 & 0 & 0 & 0 \\
6 & 2 & 1 & 2 \\
7 & 0 & 3 & 0 \\
8 & 1 & 0 & 5 \\
9 & 2 & 1 & 5 \\
10 & 0 & 2 & 4 \\
\hline Mean \pm S.D. & $0.8 \pm 0.9$ & $1.3 \pm 1.1$ & $2.2 \pm 1.9$ \\
(range) & $(0-2)$ & $(0-3)$ & $(0-5)$ \\
\hline F value & \multicolumn{3}{|c}{$3.365^{*}$} \\
L.S.D. & \multicolumn{3}{c}{0.819} \\
\hline
\end{tabular}

Table 2. Percentages of WAO as expressed by presence of mature oocytes according to worker's ages in colonies with different queen states (mean \pm S.D).

\begin{tabular}{|cccc|}
\hline $\begin{array}{c}\text { Workers' } \\
\text { ages } \\
\text { (days) }\end{array}$ & $\begin{array}{c}\text { Caged } \\
\text { mated } \\
\text { queen }\end{array}$ & $\begin{array}{c}\text { Caged } \\
\text { virgin } \\
\text { queen }\end{array}$ & Queenless \\
10 & 0 & 0 & 0 \\
12 & 0 & 0 & 0 \\
14 & 0 & 0 & $2.7 \pm 0.6$ \\
16 & 0 & 0 & $3.3 \pm 1.2$ \\
18 & 0 & $1.3 \pm 0.6$ & $3.7 \pm 1.5$ \\
20 & 0 & $2.7 \pm 0.5$ & $4.7 \pm 1.5$ \\
22 & $1.0 \pm 1.0$ & $3.0 \pm 1.0$ & $5.3 \pm 1.5$ \\
24 & $1.7 \pm 0.6$ & $3.7 \pm 0.5$ & $7.7 \pm 1.4$ \\
26 & $2.3 \pm 0.5$ & $4.0 \pm 1.0$ & $8.3 \pm 2.0$ \\
28 & $3.0 \pm 1.0$ & $5.3 \pm 0.6$ & $11.7 \pm 1.6$ \\
30 & $3.3 \pm 0.6$ & $7.3 \pm 0.6$ & $14.7 \pm 2.1$ \\
\hline
\end{tabular}

Data in Table (2) show that in the first group where colonies were headed with caged mated queens, WAO started to appear $(1 \%)$ when reached 22 days from adult emergence. As the age of workers progress until reached 30 days, the percentage of WAO in the samples increased to reach the maximum $(3.3 \%)$ at this age. In the second group when colonies were headed with caged virgin queens, the average percentage of WAO was $1.3 \%$ in workers aged 18 day old, then increased to $7.3 \%$ when reached 30 day old. In the third group (queenless colonies), the WAO started to appear early in workers aged 12 days $(1.7 \%)$ then reach a maximum of $14.7 \%$ when they were 30 day old.

The small size of the worker's ovaries is mainly attributed to the great reduction in the number of ovarioles in each ovary Table (3) being 3.33 for the right ovary and 3.6 for the left ovary with an average of 3.47 ovarioles. This agrees with the results of Ruttner, 1988 and Blom \& Verkade, 1991.

Table 3. Number of ovarioles in the ovary of the honey bee workers (mean \pm S.D).

\begin{tabular}{|cccc|}
\hline $\mathrm{n}$ & $\begin{array}{c}\text { Right } \\
\text { ovary }\end{array}$ & $\begin{array}{c}\text { Left } \\
\text { ovary }\end{array}$ & mean \\
\hline 30 & $\begin{array}{c}3.33 \\
\pm 0.99\end{array}$ & $\begin{array}{c}3.60 \\
\pm 0.96\end{array}$ & $\begin{array}{c}3.46 \\
\pm 0.79\end{array}$ \\
\hline
\end{tabular}

From the presented data it could be noticed that, WAO started to appear after 12 days from adult emergence in queenless colonies. At that time, the worker's ovary was active and reaching maturity as a result of being offered royal jelly by 
other bees via trophallactic behaviour (Hogendoorn \& Velthuis, 1988; Hilleshein et al 1989; Blom \& Verkade, 1991 and Lin \& Winston, 1998), in addition to the absence of the queen and the brood pheromones (Jay, 1970 and Seeley, 1985). Therefore, as the worker's age progresses their acceptance of queen's pheromones decreased according to the queen status.

\section{Swarm production}

As the population of bees in the colonies increased, most of beekeepers divided them few days before introducing the new queens into the new swarms. This manner encourages the appearance of WAO which was recorded an average of $1.4 \%$ two days after division, Table (4). As the time progress for one and two weeks the WAO increased significantly, being 4.8 and $9.2 \%$, respectively.

Table 4. Percentages of WAO as expressed by presence of mature oocytes in queenless nucleus after different periods of deviations.

\begin{tabular}{|ccccc|}
\hline & \multicolumn{5}{c|}{ \% of WAO } \\
\cline { 2 - 5 } Rep. & Before & \multicolumn{3}{c|}{ After division } \\
\cline { 3 - 5 } & division & 2 days & 1 week & 2 weeks \\
\hline 1 & 1 & 2 & 4 & 11 \\
2 & 1 & 1 & 7 & 13 \\
3 & 0 & 0 & 3 & 6 \\
4 & 1 & 3 & 6 & 9 \\
5 & 0 & 1 & 4 & 7 \\
\hline Mean & & & \\
\pm S.D. & $0.6 \pm 0.9$ & $1.4 \pm 1.1$ & $4.8 \pm 1.6$ & $9.2 \pm 2.9$ \\
(range) & $(0-1)$ & $(0-2)$ & $(3-7)$ & $(6-13)$ \\
\hline F value & \multicolumn{5}{|c}{2.780} \\
L.S.D. & \multicolumn{5}{|c}{} \\
\hline
\end{tabular}

\section{Queen rearing}

Queen rearing on commercial large scale yielded good incom for the beekeepers. Under the present conditions, either at the starting time (at early spring) or under the environmental conditions that not stable, the beekeepers usually use the colony as a starter and finisher for queen cells. So the colony is occupied for about ten days. The WAO were examined each day starting from the first day of rearing (grafting day) which recorded 0.4 $\%$. The percentage of WAO then increased gradually until it reached $4.6 \%$ at the tenth day (last day of rearing) Table (5). The significant differences between rearing days showed no differences either within the first 6 days $\left(1^{\text {st }}-6^{\text {th }}\right)$ or within the last 3 days $\left(8^{\text {th }}-10^{\text {th }}\right)$. The days from $6^{\text {th }}-8^{\text {th }}$ were intermediate. The present results coincide with those of Woyciechowski and Radwan (1988).

Table 5. Percentages of WAO as expressed by presence of Mature oocytes in queen rearing colonies

\begin{tabular}{|cccc|}
\hline Rearing dates & \multicolumn{3}{c|}{$\%$ of WAO } \\
\cline { 2 - 4 } $\begin{array}{c}\text { of grafted } \\
\text { larvae }\end{array}$ & Mean \pm S.D & Range & $\begin{array}{c}\text { F value } \\
\text { (L.S.D.) }\end{array}$ \\
\hline $1^{\text {st }}$ (grafting) & $0.4 \pm 0.55^{\text {a }}$ & $(0-1)$ & \\
$2^{\text {nd }}$ & $0.4 \pm 0.55^{\text {a }}$ & $(0-1)$ & \\
$3^{\text {rd }}$ & $0.6 \pm 0.89^{\text {a }}$ & $(0-2)$ & \\
$4^{\text {th }}$ & $0.6 \pm 0.89^{\text {a }}$ & $(0-2)$ & \\
$5^{\text {th }}$ & $0.8 \pm 0.84^{\text {a }}$ & $(0-2)$ & $12.145^{* *}$ \\
$6^{\text {th }}$ & $1.4 \pm 1.14^{\text {ab }}$ & $(0-3)$ & $(1.215)$ \\
$7^{\text {th }}$ & $2.6 \pm 1.11^{\text {bc }}$ & $(1-3)$ & \\
$8^{\text {th }}$ & $3.4 \pm 1.52^{\text {cd }}$ & $(1-5)$ & \\
$9^{\text {th }}$ & $4.2 \pm 0.84^{\text {d }}$ & $(3-5)$ \\
$10^{\text {th }}$ & $4.6 \pm 1.14^{\text {d }}$ & $(3-6)$ \\
\hline
\end{tabular}


From the aforementioned results it could be concluded that, the beekeepers must change their queen bees as a maximum after two years, not retard for introducing the new queens into the swarm boxes and finally they must use the starter and finisher colonies for queen rearing.

\section{REFERENCE}

Blom, J. (1993). How are duties divided between workers? Bijen. 2(2): 3537.

Blom, J. and A. Verkade (1991). Does kin recognition in honeybees, Apis mellifera L. influence the workers' chances of becoming egg layers? Animal Behaviour. 42(5): 867-870.

DeGrandi, H.G. and J.H. Martin (1993). Behaviour of egg- Laying virgin and mated queen honey bees (Apis mellifera L.) and the composition of brood in their colonies. J. Apic. Res. 32(1): 19-26. Evers, C.A. and T.D. Seeley (1986). Kin discrimination and aggression in honeybee colonies with laying workers. Animal Behaviour 34: 924-925.

Harris, J.W. and J.R. Harbo (1989). Ovary development of worker bees when caged with workers from different stocks. American Bee Jour. 129(12): 816.

Hilleshein, E.; N. Koeniger and R.F.A. Moritz (1989). Colony performance in honey bees (Apis mellifera capensis Eech.) depends on the proportion of subordinate and dominant workers. Behavioral Ecology and Sociobiology, 24(5): 291-296

Hogendoorn, K. and H.W. Velthuis (1988). Influence of multiple mating on kin recognition by worker honeybee. Naturwissenschaften. 75: 412-413.
Hoover, S.E.R.; C.I. Keeling; M.L. Winston and K.N. Slessor (2003). The effect of queen pheromones on worker honeybee ovary development. Naturwissenschaften. 90(10): 477-480.

Jay, S.C. (1970). The effect of various combinations of immature queen and worker bees on the ovary development of worker honeybees in colonies with or without queens. Canadian Journal of Zoology. 48:169-173.

Katzav, G.T.; V. Soroker; J. Kamar; C.M. Schulz; W. Francke and A. Hefetz (2003). Ultrastructural and chemical characterization of egg surface of honeybee worker and queen-laid eggs. Chemoecology. 13(3): 129-134.

Lin, H.R. and M.L. Winston (1998). The role of nutrition and temperature in ovarian development of the worker honey bee (Apis mellifera). Candian Entronologist. 130( 5): 883-891.

Moritz, R.F.A.; M. Beye and H.R. Hepburn (1998). Estimating the contribution of laying workers to population fitness in African honey bees (Apis mellifera) with molecular markers. Insects Sociaux. 115( 3): 277 - 287.

Ruttner,F. (1988). Geographic variability. In: Ruttner, F. (ed). Biogeography and Taxonomy of Honeybees. Pp. 45-47. Springer-Verlag Berlin Heidelberg, Germany.

Seeley, T.D. (1985). Queens and Workers: Reproductive division of labor. In: Seeley, T.D. (Ed) Honeybee Ecology pp. 23-25. Princeton University Press. New Jersey, USA.

Visscher, P.K. (1996). Reproductive conflict in honey bees: a stalemate of worker egg- laying and policing. Behavioral Ecology and Sociobiology. 39(4): 237-244. 
Woyciechowski, M. and J. Radwan (1988). Kin recognition in rearing and acceptance of queen honey bees. Pszczel nicze Zeszyty Naukowe. 32: 3543.

Woyke, J. (1993). Some behavioural characteristics of the Sudanese honeybee.

Bee World. 74( 3): 133-140.

\section{بحلة اتحاد الجامعات العربية للدراسات والبحوث الزراعية، جامعة عين شمس، القاهرة ، 13(2)، 513-519، 2005 \\ حدوث الأمهات الكاذبة فى طوائف نحل العسل تحث ظروف مختلفة}

[33]

\section{عادل محمد البسيونحى}

$$
\text { 1- قسم وقاية النبات - كلية الزراعة - جامعة عين شمس - شبرا الخيمة - القاهرة - مصر }
$$

الى 30 يوما فقد بلغت نسبة حدوث الأمهات

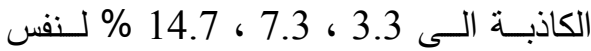
الطوائف السابق ذكرها على التوالى.

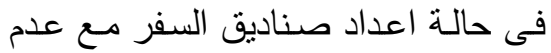

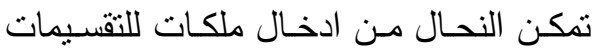

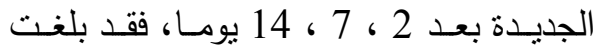
نسبة الامهـات الكاذبـة فى عينـات الثــالات

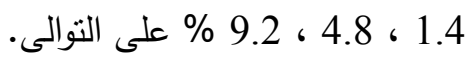
نسب نواجد الامهات الكاذبـة فى عينـات الشغالات المأخوذة من طوائف تربية الملكات

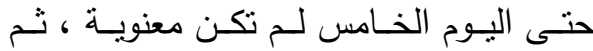
ازدادت نسـبة هـذة الامهـات الكاذبـة تدريجيا الى ان وصلت الى 4.6 \% فى اليوم العاثر

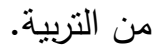

درســت الأمهــات الكاذبــة معبــرا عنهــا

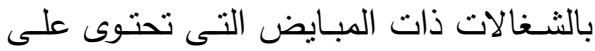
بـيض ناضـج فـى طوائف نحل ذات ذلكـات كرينوليـة ملقحـة طبيعيـا. وقد أظهرت فئن النتائج

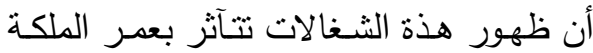

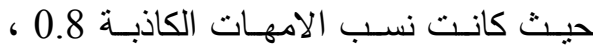
1.3 ، 2.2 \% فى عينات الطوائف التجريبية تزاوحت أعمار ملكاتها 10، 20 ، 30 شـهرا على التوالى. يبـدأ مبـيض الثـغالة فيى النشـاط عندما

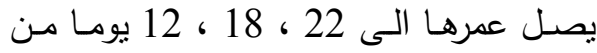

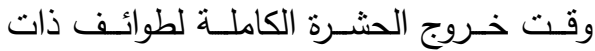

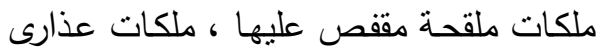

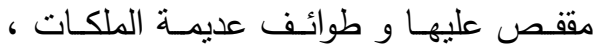

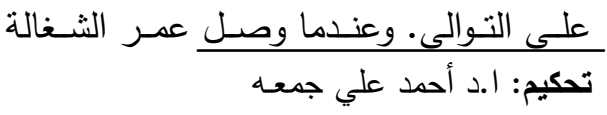

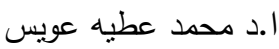

